\title{
Discovering new floral visitors of four Chilean endemic orchids
}

\section{Descubriendo nuevos visitantes florales de cuatro orquídeas endémicas chilenas}

\author{
Víctor H. Monzón ${ }^{1}$, Rodrigo O. Araujo ${ }^{1,2 *}$, Patricio Avendaño ${ }^{1}$, Rubén Garrido ${ }^{1}$ \& José N. \\ Mesquita-Neto ${ }^{1,2}$
}

${ }^{1}$ Laboratorio de Ecología de Abejas, Departamento de Ciencias Biológicas y Químicas, Facultad de Ciencias Básicas, Universidad Católica del Maule, Avenida San Miguel, 3605 , Talca, Chile.

${ }^{2}$ Centro de Investigación de Estudios Avanzados del Maule, Vicerrectoría de Investigación y Postgrado, Universidad Católica del Maule, Avenida San Miguel, 3605, Talca, Chile.

*Email: araujorodrigodeoliveira@gmail.com

\begin{abstract}
Orchidaceae is a diverse group with conservation issues all over the World. Due to its endangered situation, knowledge about its reproductive biology is needed to plan conservation strategies. We conducted a study during October 2016 and October 2017 in Maule region, Chile, and discovered the following unreported interactions: Colletes seminitidus Spinola and Astylus trifasciatus Guér. transferring pollen from Bipinnula fimbriata; Centris nigerrima (Spinola) transferring pollen from Chloraea bletioides; Cadeguala occidentalis (Haliday) flower-visiting Chloraea gavilu; Centris cineraria Smith and Megachile saulcyi Guérin-Méneville transferring pollen from Gavilea venosa.
\end{abstract}

Keywords: Maule Region, native insects, pollination.

\section{RESUMEN}

Orchidaceae es un grupo diverso, amenazado en todo el mundo. Debido a su situación de peligro, el conocimiento sobre su biología reproductiva es necesario para planificar estrategias de conservación. Hemos realizado un estudio durante octubre de 2016 y octubre de 2017 en la Región del Maule, descubriendo las siguientes interacciones no reportadas: Colletes seminitidus Spinola y Astylus trifasciatus Guér. visitando Bipinnula fimbriata; Centris nigerrima (Spinola) visitando Chloraea bletioides; Cadeguala occidentalis (Haliday) visitando Chloraea gavilu; Centris cineraria Smith y Megachile saulcyi Guérin-Méneville sacando polen de Gavilea venosa.

Palabras clave: insectos nativos, polinización, Región del Maule.

The Orchidaceae has around 25,000 species (Novoa et al. 2015), being considered one of the most abundant families of the entire vegetal kingdom (Jersáková et al. 2006). All over the World, orchids have been decreasing due to different environmental pressures, thus limiting its distribution and susceptibility that may cause large-scale extinction events under future climate changes (Swarts \& Dixon 2009), besides local factors such as habitat loss and over-collection (Huang 2011). Considering its key role in one ecosystem and its endangered situation, orchids are often used as a critical group in biological conservation (Baillie et al. 2004). All these characteristics make it important to know about these plants' reproductive biology, as well as to explore their distribution and conservation status (Zhang et al. 2015).

Orchids are widely distributed in the tropics and subtropics (Cribb et al. 2003). In Chile, they are distributed from Arica to Tierra del Fuego, reaching 72 species of eight genera (Novoa et al. 2015). Despite being a very specialized and diverse group, the Orchidaceae is possibly one of the less studied families of flowering plants in Chile and their biology, ecology and taxonomy remain largely unknown (Lehnebach \& Riveros 2003). 
Orchid pollination is extremely diversified, including rewarding and deceptive systems and various behavior types. This variation in motivation and outcome of flower visits by the pollinator is expected to affect patterns of pollinator specialization (Schiestl \& Schluter 2009). The orchid-pollinator interaction seems to be so ancient that the fossil of an extinct orchid was found together with a stingless bee with the respective pollinium attached to its body (Meliorchis caribea and Proplebeia dominicana (Wille \& Chandler 1964) (Hymenoptera: Apidae), see Ramírez et al. 2007).

The interaction between the Chilean native orchids and their pollinators is an invaluable research line to the study of plant evolution, but it requires a lot of effort in the fieldwork and long-time frames (Novoa 2005). Information about the biology and interaction with other organisms is necessary to plan conservation strategies for native orchids. Thus, it is becoming extremely important to carry out empirical studies to expand the knowledge of this family in Chile.

On this note, we report six unreported pollinator orchids interactions to four Chilean native orchid species: Bipinnula fimbriata (Poepp.) I.M. Johnst., Chloraea bletioides Lindl., Chloraea gavilu Lindl. and Gavilea venosa (Lam.) Garay \& Ormerod. The study was conducted during October of 2016 and 2017, coinciding with the flowering periods of the species (Francioli \& Quezada 2009), in three different locations in the Maule Region, Chile (Armerillo, Batuco and Putú). We performed focal observations of $B$. fimbriata and $C$. bletioides

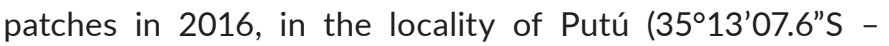
$72^{\circ} 16^{\prime} 57.3^{\prime \prime} \mathrm{W}$ ), and patches of C. gavilu and G. venosa in 2017,

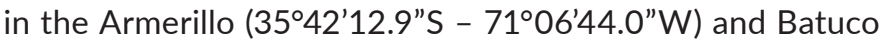
locations (3506'53.2"S - 71'57'14.3"W), respectively.

Regarding the studied areas, they are all in the Maule Region and share the Mediterranean climate type. Putú Wetland has a strong maritime influence that is reflected in moderate temperatures throughout the year, which on average, fluctuates between $11^{\circ} \mathrm{C}$ to $13^{\circ} \mathrm{C}$. This area has a dry season of five to seven months and the rainfall is concentrated in the months that correspond to autumnwinter, with an annual average of $943 \mathrm{~mm}$ (Santibáñez \& Uribe 1993). Armerillo has a dry season in spring-summer and greater thermal amplitude, fluctuating between $7^{\circ} \mathrm{C}$ (winter) to $31^{\circ} \mathrm{C}$ (summer), and precipitations levels that vary between $1700 \mathrm{~mm}$ to $1800 \mathrm{~mm}$ during the year, including snowfalls during the winter (Casanova et al. 2004). Batuco has an attenuated marine influence, with a dry season of five to six months, average temperatures between $12^{\circ} \mathrm{C}$ to $13^{\circ} \mathrm{C}$ and precipitations that reach approximately $800 \mathrm{~mm}$ annually on average (Montero et al. 2007).

The observations were registered in 7-10 sunny days during the orchids flowering period. All the floral visitors who had the pollinium attached to its body after visiting a flower were registered, trough continuous observation between $09 \mathrm{hrs}$ to $18 \mathrm{hrs}$. Whenever possible, we also photographed (with two exceptions mentioned below) and captured the flower visitors with an entomological net to identify the species in the Laboratorio de Ecología de Abejas of the Universidad Católica del Maule, Talca, Chile.

For the orchid pollination to occur, first, a morphological match between flower and pollinator is required to remove the pollinium and transfer it to the subsequent flower (Ramírez et al. 2007), moreover the effective transfer of pollen triggering reproduction and seed set based on these candidate visit must be demonstrated (Kearns \& Inouye 1993). Regarding this premise, we considered a pollinator candidate to be only those flower visitors that carried the pollinium of an orchid flower to another.

For the first time Colletes seminitidus Spinola 1851 (Hymenoptera: Colletidae) and Astylus trifasciatus (GuérinMéneville 1844) (Coleoptera: Melyridae) (Fig. 1a) are recorded foraging at B. fimbriata. In addition to the species found in this study, Colletes musculus Friese 1910 (Hymenoptera: Colletidae) and Chaenohalictus sp. (Hymenoptera: Halictidae) were previously observed carrying a pollinium of this orchid (Francioli \& Quezada 2009). For Chloraea bletioides, Centris nigerrima (Spinola 1851) (Hymenoptera: Apidae) was found for the first time transporting a pollinium from one flower to another (Fig. 1b). Previously, Celis et al. (2004) had observed this same behavior in two beetles: Arctodium vulpinus (Erichson 1835) (Coleoptera: Glaphyridae) and Astylus trifasciatus Guér.

In this study, we also made an unreported registration of Cadeguala occidentalis (Haliday 1836) (Hymenoptera: Colletidae) carrying a pollinium of Chloraea gavilu, besides Centris cineraria Smith 1854 (Hymenoptera: Apidae) (Fig. 1c) and Megachile saulcyi Guérin-Méneville 1844 (Hymenoptera: Megachilidae) (Fig. 1d) a pollinium of G. venosa. Although we observed Apis mellifera L. 1758 (Hymenoptera: Apidae) and Bombus terrestris L. 1758 (Hymenoptera: Apidae) visiting C. gavilu and other floral visitors are known for these two orchids (Celis et al. 2004, Novoa 2005), insects that are able to carry their pollinium were registered for the first time in this study.

Although we reported here bees carrying pollinium from orchid flowers, we cannot consider them as pollinators, because our study has some methodological limitations. We did not report details about the frequency of visits, the timing of foraging activity neither species accumulation curves. These aspects are important to distinguish among the floral visitors, which are effective pollinators (Schemske 
et al. 1984, Kandori 2002, Herrera 1990). However, the recognition of the orchid pollinator candidates reported here opens a precedent for more specific studies, such as the confirmation of their pollination services based on single visit effectiveness as well as the comparisons of pollinating efficiency and determination of the mechanisms involved in such interaction. The knowledge about the reproductive biology of native orchids, is fundamental for any further plans for their conservation; hence, it is a group with great potential for future studies.
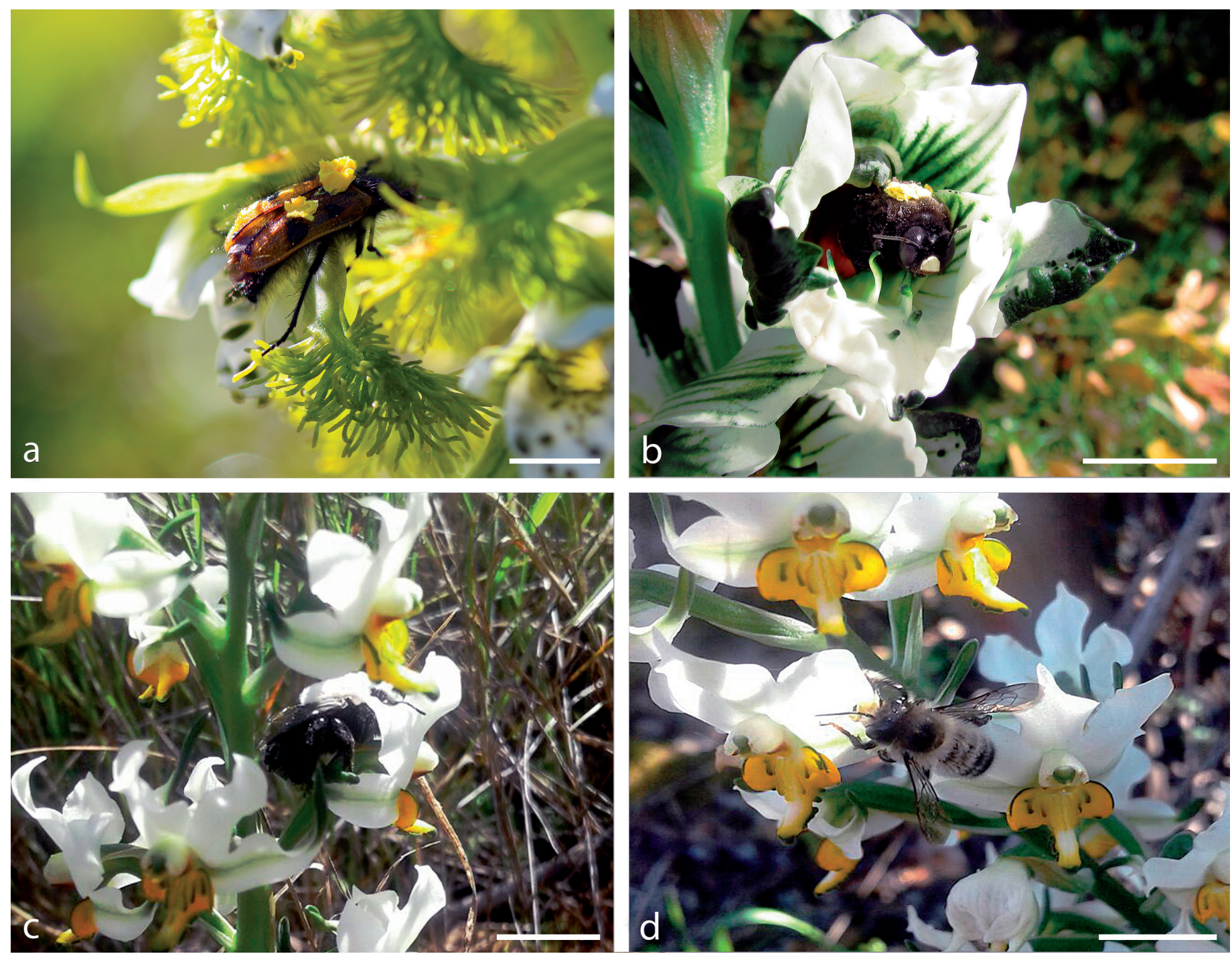

FIgURE 1: New records of floral visitors associated with Chilean endemic orchids: (a) Astylus trifasciatus Guér. carrying a pollinium of Bipinnula fimbriata above it elytra; (b) Centris nigerrima (Spinola) carrying a pollinium of Chloraea bletioides above it mesosoma; (c) Centris cineraria Smith and (d) Megachile saulcyi Guérin-Méneville carrying a pollinium of Gavilea venosa on their frons. Scale bars (mm): Figs. (a) and (b) = 10; Figs. (c) and (d) = 5. / Nuevos registros de visitantes florales asociados a orquídeas endémicas chilenas: (a) Astylus trifasciatus Guér. Ilevando un polinio de Bipinnula fimbriata encima de sus élitros; (b) Centris nigerrima (Spinola) Ilevando un polinio de Chloraea bletioides encima de su mesosoma; (c) Centris cineraria Smith y (d) Megachile saulcyi Guérin-Méneville llevando un polinio de Gavilea venosa en sus caras. Barras de escala (mm): Figs. (a) y (b) = 10; Figs. (c) y (d) $=5$. 


\section{ACKNOWLEDGEMENTS}

We would like to thank the Ministerio del Medio Ambiente and the Fondo de protección ambiental (FPA NAC-I-025-2014) for providing the necessary resources for the realization of this research.

\section{REFERENCES}

Baillie, J., Hilton-Taylor, C., Stuart, S.N. 2004 IUCN red list of threatened species: a global species assessment. IUCN. $191 \mathrm{pp}$.

Casanova, M.P, Elizondo, W.V., Leighton, W.L., Guerreros, O.S. 2004. Edafología-Guía de clases prácticas. Ediciones Universidad de Chile, Santiago, Chile. 74 pp.

Celis, J., Fernandéz, P., Guzmán, C. 2004. Diversidad de insectos visitantes en cuatro especies del género Chloraea (Orquidacea). Departamento de Biología y Química, Universidad de Playa Ancha de Ciencias de la Educación, Valparaíso, Chile. 85 pp.

Cribb, P.J., Kell, S.P., Dixon, K.W., Barrett, R.L. 2003. Orchid conservation: a global perspective. En: Orchid conservation: 1-24. Natural History Publications, Kota Kinabalu, Sabah.

Francioli, S.E., Quezada, P.N. 2009. Orquídeas de la Región de Valparaíso. Taller La Era, Viña del Mar, Chile. 82 pp.

Gaskett, A.C. 2011. Orchid pollination by sexual deception: pollinator perspectives. Biological Reviews 86: 33-75.

Herrera, C.M. 1990. Daily patterns of pollinator activity, differential pollinating effectiveness, and floral resource availability, in a summer-flowering Mediterranean shrub. Oikos 58: 277-288.

Huang, H. 2011. Plant diversity and conservation in China: planning a strategic bioresource for a sustainable future. Botanical Journal of the Linnean Society 166: 282-300.

Jersáková, J., Johnson, S.D., Kindlmann, P. 2006. Mechanisms and evolution of deceptive pollination in orchids. Biological Reviews 81: 219-235.

Kandori, I. 2002. Diverse visitors with various pollinator importance and temporal change in the important pollinators of Geranium thunbergii (Geraniaceae). Ecological Research 17: 283-294.

Kearns, C., Inouye, D. 1993. Techniques for pollination biologists. University Press of Colorado.

Lehnebach, C., Riveros. M. 2003. Pollination biology of the Chilean endemic orchid Chloraea lamellata. Biodiversity and Conservation 12: 1741-1751.

Montero, A., San Martín, J., Tamayo, M., Muñoz, C. 2007. La cordillera de la Costa en la Región del Maule. Su patrimonio natural, cultural e histórico. Publicación del Programa de Biodiversidad y Ecosistemas, Talca, patrocinado por Gobierno de Chile, CONAMA y Consejo Nacional de la Cultura y las Artes. 252 pp.

Novoa, P. 2005. Algunos alcances a la interacción entre insectos y orquídeas. Revista del Jardín Botánico Chagual 3: 32-37.

Novoa, P., Espejo, J., Alarcón, D., Cisternas, M., Domínguez, E. 2015. Guía de Campo de las Orquídeas Chilenas. Segunda edición. Editora Corporación Chilena de la Madera, Concepción, Chile. 244 pp.

Ramírez, S.R., Gravendeel, B., Singer, R.B., Marshall, C.R., Pierce, N.E. 2007. Dating the origin of the Orchidaceae from a fossil orchid with its pollinator. Nature 448 (30): 10421045.

Santibáñez, F., Uribe, J. 1993. Atlas Agroclimático de Chile. VI, VII, VIII y IX Regiones. Laboratorio de Agroclimatología, Facultad de Ciencias Agrarias y Forestales, Universidad de Chile. Ministerio de Agricultura. Fondo de Investigación Agropecuaria. Corporación de Fomento de la Producción, Santiago. 99 pp.

Schemske, D.W., Horvitz, C.C. 1984. Variation among floral visitors in pollination ability: a precondition for mutualism specialization. Science 225: 519-522.

Schiestl, F.P., Schluter, P.M. 2009. Floral isolation, specialized pollination, and pollinator behavior in orchids. Annual Review of Entomology 54: 425-446.

Swarts, N.D., Dixon, K.W. 2009. Terrestrial orchid conservation in the age of extinction. Annals of Botany 104: 543-556.

Zhang, Z., Yan, Y., Tian, Y, Li, J., He J., Tang, Z. 2015. Distribution and conservation of orchid species richness in China. Biological Conservation 181: 64-72.

Received: 08.07.2019

Accepted: 14.10.2019 